\title{
EFFECT OF SANDBLASTING TIME ON THE ROUGHNESS OF THE METAL COBALT- CHROMIUM (co-cr) DURING DENTURE METAL FRAMEWORK PRODUCTION
}

\author{
Endang Kusdarjanti, Dwiyanti Feriana R, Eny Inayati \\ Faculty of Vocational Education, Airlangga University, Surabaya
}

\begin{abstract}
ABSTRAK
Salah satu tahap pembuatan gigi tiruan kerangka logam yaitu sandblasting, yaitu membersihkan sisa-sisa bahan tanam tuang setelah proses penuangan logam dan sisa-sisa oksida pada permukaan logam. Setelah dilakukan fitting pada model kerja, kemudian kerangka logam gigi tiruan dilakukan sandblasting lagi sampai halus sebelum dilakukan elektropolishing. Alat yang digunakan adalah sandblaster ,bahannya Al2O3 (Alumunium oxide) ukuran 250 ?m. Waktu yang diperlukan sekitar 1 menit, akan tetapi waktu 1 menit tersebut bila diaplikasikan pada praktikum mahasiswa D3 masih belum bersih dan masih ada sisa-sisa bahan tanam tuang serta oksida di permukaan logam Co-Cr. Tujuan penelitian adalah untuk mengetahui pengaruh waktu sandblasting pada pembutan gigi tiruan kerangka logam terhadap kekasaran permukaan logam Co-Cr. Penelitian ini adalah penelitian experimental laboratories. Bentuk sampel berupa tablet dengan diameter $7 \mathrm{~mm}$, tebal logam $2 \mathrm{~mm}$. Jumlah sampel 24 tablet dibagi menjadi 4 kelompok setiap kelompok terdiri dari 6 tablet sampel. Pembagian kelompok sampel penelitian adalah sebagai berikut; Kelompok 1; Sandblasting permukaan logam dengan AL2O3 250 ?m waktu 1 menit, Kelompok 2; Sandblasting permukaan logam dengan AL2O3 250 ?m waktu 2 menit, Kelompok 3; Sandblasting permukaan logam dengan AL2O3 250 ?m waktu 3 menit, Kelompok 4; kelompok tidak dilakukan sandblasting. Data dianalisis dengan analisis statistik anava satu jalur dengan taraf kemaknaan 0.05. Apabila ada perbedaan yang bermakna antar kelompok duiji dengan uji HSD. Ada perbedaan yang bermakna pada kekasaran permukaan logam Co-Cr antara kelompok kontrol yang tanpa disemprot dengan kelompok yang di semprot 1 menit, 2 menit, dan 3 menit. Sebagai simpulan, permukaan kerangka logam yang tidak dilakukan sandblasting lebih kasar dibandingkan dengan yang dilakukan sandblasting. Semakin lama waktu sandblasting semakin menghasilkan permukaan kerangka logam yang halus. Sandblasting yang sempurna memerlukan waktu yang cukup yaitu 2-3 menit. (FMI 2016;52:160-168)
\end{abstract}

Kata kunci: sandblasting, gigi tiruan kerangka logam, kekasaran permukaan, logam CoCr

\begin{abstract}
One of the stages of manufacture of denture metal framework that is sandblasting, ie cleaning the remnants of investment material after metal casting process and remnants of metal oxide on the surface. After fitting in the master model, then the metal framework dentures do sandblasting again until smooth before elektropolishing. The tools used are sandblaster, material Al2O3 (aluminum oxide) size of $250 \mathrm{~lm}$. The time it takes about 1 minute, but the time of 1 minute when applied to student practicum D3 is still not clean and there are still remnants of planting material castings and metal oxide on the surface of the Co-Cr. Objective: To determine the effect of time on pembutan teeth iruan sandblasting the metal frame of the metal surface roughness Co-Cr. This study is experimental laboratories. A sample of tablet shape with a diameter of $7 \mathrm{~mm}, 2 \mathrm{~mm}$ thick metal. Number of samples 24 tablets were divided into 4 groups each group consisting of six tablet samples. Distribution of the sample group of the study are as follows; Group 1; Sandblasting metal surfaces with 250 ?m Al2O3 time of 1 minute, Group 2; Sandblasting metal surfaces with Al2O3 250 ?m 2 minutes, Group 3; Sandblasting metal surfaces with Al2O3 250 ?m 3 minutes, Group 4; the group did not do sandblasting. Data were analyzed with ANOVA statistical analysis of the lane with 0:05 significance level. If there is a significant difference between groups duiji with HSD test. There were significant differences in surface roughness Co-Cr metal between the control group without sprayed with the spray group at 1 minute, 2 minutes and 3 minutes. In conclusion, the surface of a metal frame that is not done sandblasting coarser than done sandblasting. The longer the time sandblasting increasingly produce a smooth surface of a metal frame. Sandblasting is perfectly need sufficient time is 2-3 minutes. (FMI 2016;52:160-168)
\end{abstract}

Keywords: sand blasting, metal frameworks, surface roughness, CoCr alloy

Correspondence: Endang Kusdarjanti, Teknik Kesehatan Gigi, Fakultas Vokasi Universitas Airlangga. Jl. Srikana Surabaya - Indonesia. E-mail: endangkusdarjanti@yahoo.co.id

\section{INTRODUCTION}

Denture base is part of the denture rests on soft tissue and denture elements were attached. The materials used in the manufacture of denture base is divided into two groups: metals and non-metals, and one of the non- metallic base material is acrylic resin (Manappalil 2003).

Materials acrylic resins are still commonly used on base removable denture because it has advantages, among others: easily processed and polished, has a nice 
aesthetic is also biocompatible, but this material is easily broken, especially when the thickness is minimum, so it requires a certain thickness (Anusavice 2003), Therefore, the selection of the denture with the base metal framework is still an option because it has an advantage over denture base made of acrylic resin, among others: does not absorb water, rigid, can be made as thin as possible, and convenient. However denture with the base metal framework is relatively expensive compared to the denture base acrylic resin because requires a longer process (Prabowo 2008).

Denture framework metal is an artificial tooth that consists of a base made of metal frames Castings (co-cr) and parts saddle of acrylic resins as well as elements of the denture, in the framework of the metal it contains one or more grating to a saddle acrylic, The main connector, the auxiliary connector, the retainer direct and indirect retainer (Prabowo 2008). Terms of denture base metal frame is rigid, biocompatible, stable, comfortable to wear by the patient, and base metal harusbenar completely smooth and glossy to prevent the buildup of food residue (HUDIS 1977).

In the manufacture of denture metal framework there are three kinds of metal used is nickel-chromium, cobalt-chromium, and titanium. Titanium is used for denture base metal framework is a class of pure titanium (Ti) (Nort 2003). For the manufacture of laboratory procedures denture metal framework necessary expertise and very high accuracy of a dental technician and dentist. The steps of preparing denture metal framework include surveys and blockout, design, duplication of models, coatings, wax up, spruing, investing, burn out, casting, sandblasting, fittings, sandblasting, elktropolishing, finishing and polishing (Knezovic 2003).

One stage in the manufacture of denture metal framework is sandblasting. Sandblasting is a process of treatment in the form of spraying partkel-abrasive particles are strong and focused on the metal surface to clean up the remnants of planting materials and metal oxides (Kumar et al 2013). After a clean metal surface of the remnants of planting materials and metal oxides then do next stage is the process elektropolishing.

Surface roughness is a measure of the lack of rules on the metal surface that has been processed and polished end (Powers \& Wataha 2008) Sandblasting is one of the recommended methods to create a texture of surface roughness on the metal (Wang et al, 2010). The materials used for sandblasting sand $\mathrm{Al} 2 \mathrm{O} 3$ alumina (aluminum oxide), the sands have varying particle sizes commonly used in the manufacture of denture metal framework is 250 ? M/60 mesh. While the time required to process sandblsting on making denture metal framework around 90 seconds - 1 minute (Kueh \& Fazal 2012). But this time when applied to student practicum D3 Faculty of Vocational still not clean and there are still remnants of planting material castings and metal oxide on the surface. Metal used cobalt-chromium (cocr).

Until now D3 students for practical manufacture of denture metal framework at this stage of time used for sandblasting to clean from the remnants of planting materials castings and metal oxide on the surface of the co-cr yet known with certainty. To get to the stage elektropolishing sandblasting phase must be completely clean of the remnants of planting material castings and metal oxide on the surface of the co-cr, so that the next stage will be maximized, so that the metal framework tuangnya results will be more accurate. Until now, research on the effects of time on the manufacture of denture sandblasting the metal framework on surface roughness of the metal cobalt-chromium (co-cr) has never been done. From the background of the above raised the question Is there a sandblasting effect on the surface roughness of the metal co-cr? The purpose of this study was to determine the best time so that the results obtained from sandblasting is really clean from the remnants of planting materials castings and metal oxide on the surface of the metal co-cr using Al2O3 material so ready to be done elektropolishing stage. We hope this research can provide input for dental technicians, dentists and dental students to be on time practicum D3 denture metal framework, can know the right time to sandblasting.

\section{Most Removable Denture}

Removable partial dentures are artificial teeth that replaces one or more, but not all of the teeth and surrounding tissue and is supported by teeth or underlying tissue, as well as the generated-can be put into the mouth by the patient (Loney, 2011). The function of the removable partial denture is to improve the function of mastication, restoring the aesthetic function, improve the function of speech, as well as maintaining the tissues of the mouth are still there and to stay healthy. Removable partial dentures secured the support of the natural tooth is still lagging behind and the underlying tissue as an abutment (Henderson1995).

According to Craig \& Powers (2002) terms of material manufacture base removable denture, among others, has the strength and durability in the solubility and absorption of the oral fluid, has thermal properties and accuracy of processing good dimensional stability, absence of taste and smell, biocompatible against oral conditions, natural color stability, ease of manipulation 
of manufacture and repair, and affordable cost. There are 2 types of removable partial dentures is based on the materials used, the denture with acrylic resin base, and the denture with the base metal framework, both the material has its advantages and disadvantages of each (Loney 2011).

Denture metal framework is a removable partial denture base material is made of solid metal frame co-cr. In the framework of the metal are major connector, minor connector, retrainer direct, indirect retrainer, and a saddle as a denture acrylics and elements (Loney 2011) .Gigi imitation metal framework more favorable than dentures are made of acrylic resin, for denture metal framework does not absorb water, rigid, can be made as thin as possible on the connector area so it is more hygienic and comfortable to wear (Prabowo, 2008). Making dentures metal frame through a long process so costly compared denture acrylic resin.

Denture metal framework have aspects of mechanical and biological aspects which are important in providing retention and comfort of the denture, the metal element in the arms rigid since clamps are attached to the abutment teeth that will determine the retention and stabilization during denture work. Biological aspects usually associated with comfort and the ability for dirt resistant and especially in the marginal gingiva (Pintadi, 2013). Although the metal material has good strength, resistance to fracture and abrasion, but has a weakness as costly and less esthetic received by the patient (Singh \& Gupta 2013).

Phase manufacture of denture metal framework that survey, blockout, duplicating, coating, wax up, spruing, Investing, burn out, casting, sandblasting, finishing, polishing, and electropolishing (Knezovic 2003, Renvert 2008). The metal used for the manufacture of denture metal framework is from the class base metal alloy is nickel chromium alloy, cobalt chromium alloy, titanium cobalt chromium metal alloy.Untuk (co-cr), hereinafter referred to co-cr metal was first introduced to the profession of dentistry in the $1930 \mathrm{~s}$, and since it effectively replaces the type IV gold alloy metals for the manufacture of metal framework partial denture, especially because the cost is relatively low, and mechanical properties are adequate. These alloys harder than gold mixture. Because of the hardness of metals co-cr this then requires the use of special tools for cutting and finishing polished, which is a significant factor with good casting (Noort 2002).

The co-cr metal composition consisting of an alloy of cobalt (co) 55-65\%, chromium (Cr) $30 \%$, with the addition of $0-10 \%$ nickel, 0.2 to $0.25 \%$ carbon, and molybdenum (4-5\%). Cobalt and chromium alloys that form a cobalt-chromium. The modulus of elasticity of the metal co-cr is typically $250 \mathrm{GPa}$, whereas the blend modulus is in the range of 70-100 GPa (Noort 2002). For the properties of metals is co-cr of each component that is co causing these hard alloy is strong and rigid, to cr components provide corrosion resistant properties, while the components ni reduces the strength and should be added ductility, and reacted with carbid. The melting point of the metal is between $1250 \mathrm{oC}$ co-cr-500oC. In general, the higher the chromium content, the better the corrosion resistance, therefore, manufacturers try to maximize the amount of chromium without introducing kerapuhanya stage. This has the added benefit that results in solutions that significantly affect the hardening when added to grain besi.Adapun metal co-cr advantage of this is to have the element carbon in a small amount, after being added to the co-cr metal composition will yield strength, hardness and density, Carbon can combine with one of the elements gold alloy to form carbides. However, it is certain that there is no excess carbon is absorbed by the alloy of gold during the process of melting the metal in the casting.

Distribution of carbide also depends on the casting temperature and cooling rate so that no shrinkage. These co-cr metal hardness is increased and requires the use of special finishing tools for cutting and smoothing. Polishing is an important step to complete denture metal framework and polishingnya inaccurate if it will cause a buildup of dental plaque on the surface of the metal and cause corrosion, therefore, the metal surface should be made as smooth as possible. While metal loss co - cr this is to have a high resistance to abrasion, making it more difficult for the dental technician working on the denture metal framework, but the cause abrasion resistance properties in a longer period of time. Further, for the dental technician, metal alloy is much harder to handle than gold because the metal alloy mix must be heated to a high temperature before being cast. For the casting process temperature is in the region of 1500$1550{ }^{\circ} \mathrm{C}$ and the association casting shrinkage of $2.0 \%$. With induction-type centrifugal casting machine, which has a high strength to be able to melt metal mix (Noort 2002).

Sandblasting according Widyarta et al (2015) is a mechanical process to clean and change the surface roughness. Sandblasting is done by spraying sand or micron size particles are hard and sharp with a relatively high velocity in the surface layer, (Fig. 1.). The collision of grit or micron size particles are on surfaces with relatively high velocity resulting in local plastic deformation on the surface, which causes the material surface topography changes or changes in surface roughness. The magnitude of changes in topography or surface roughness depends on the speed/pressure spray, 
the particle size, the mechanical properties of the particles and the duration of the collision process.
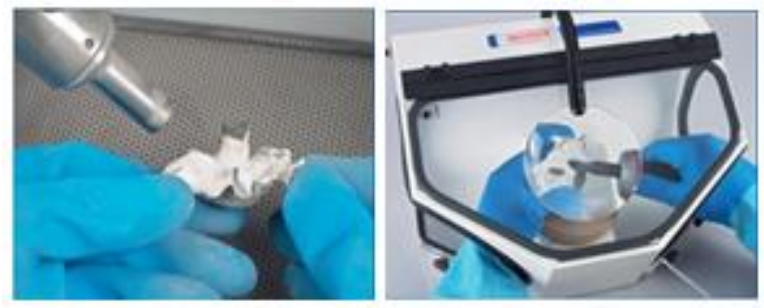

Fig. 1. The process of sandblasting (Renvert 2008)

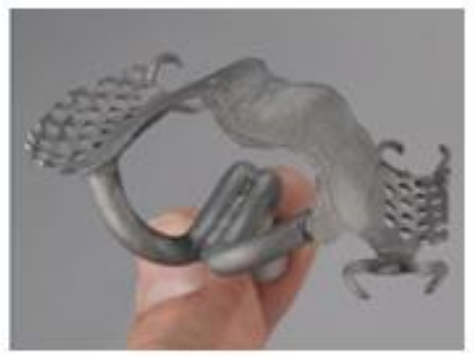

Fig. 2. The remains of planting material is lost (Renvert 2008)

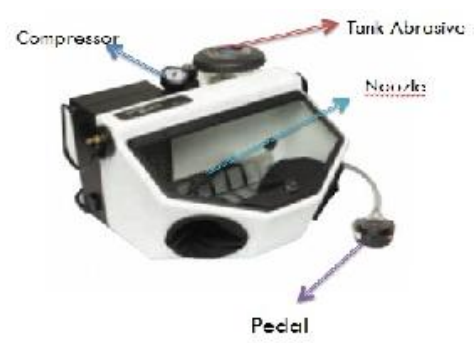

Fig. 3. The parts of the sandblaster (Usdentaldepot 2016)

The tools used to make the process of sandblasting is sandblaster. Consisting of tank or tube containing abrasive material, compressors containing air pressure as a medium to remove abrasive material, noozle as where the discharge of abrasive materials that have been mixed with the air pressure of the compressor, and pedal as a foothold regulator of the instrument sandblaster (Usdentaldepot 2016). (Fig. 3).

In the process by spraying abrasive material with air pressure $0.4 \mathrm{Mpa}$ at an angle of $90^{\circ}$ from the surface of the metal directionally (Fig. 1) (Slatineanu et al 2011).

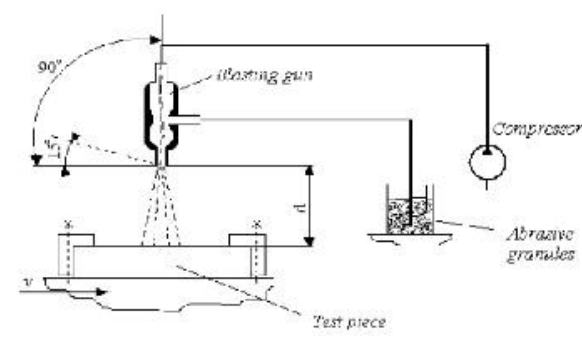

Fig. 4. Scheme of the workings of the tool sandblaster (Slatineanu et al 2011)

The main objective of sandblasting to clean the metal surface, it also improves bonding surface with micromechanical retention and lower the surface tension (Kumar et al 2013). Benefits sandblasting according to generate mechanical interlocking as a result of air pressure sandblaster that will add strength and improve surface wetting metal (Carpenter \& Goodkind 1979). Sandblasting for denture metal framework include abrasive blasting or sandblasting is used by many processes on a production in the industry, in order to form a surface texture of an object to the parameter desired, usually at each production using a technique different (Pietnicki et al 2014 ). Sandblasting process by spraying abrasive material is strong and focused on the surface of an object by using air pressure (Saif corp 2008). Materials used in abrasive material must have the hard particles (Anusavice 2003). There are three types of abrasive materials used in dentistry, namely finishing, polishing, and abrasive cleansing. Finishing abrasive generally had a hard particles normally used for mempreparasi teeth. Polishing abrasive has a particle size that is lower than the finishing abrasives, normally used to smooth and polish a prosthesis. Cleansing abrasive particles in general have a very soft with a very small particle size (micron), is used to remove material that is difficult to clean and accessible and to create a texture of surface roughness (Powers and Wataha, 2008). According Anusavice (2003) abrasive materials that can be used is divided into two, namely: Natural abrasives, these materials are Arkansas stone, chalk, corundum, diamond, emery, garnet, pumice, quartz (silicon dioxide), sand, tripoli, and zirconium silicate, And the Manufactured Abrasives, is included synthetic substances which generally have better physical properties, the material is silicon carbide, aluminum oxide, synthetic diamond, rouge, and tin oxide. The material used for sandblasting is aluminum oxide (Al2O3) is a synthetic material with a white powder that has more violence than carborundum (natural alumina) because of its purity. Such materials are processed with different properties and a slight change of the reactants during the manufacturing process (Anusavice2003). Aluminum oxide shown in Fig. 5. 


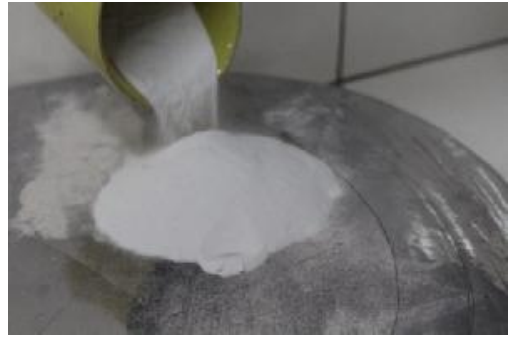

Fig. 5. Aluminum oxide sand (http://www.myworld hut.com)

Aluminium oxide (A12O3) is a synthetic material with the powder (sand) white have a higher hardness than carondum (natural alumina) because of its purity. Such materials are processed with different properties and a slight change of the reactants during the manufacturing process (Anusavice 2003). Al2O3 with a size of 250? M just cleaning the precious metal without the mix, but can also be used to clean metal surfaces. Sandblasting should be able to produce a co-cr metal surfaces clean without the undercut.

In this study by using a sandblasting process materials $\mathrm{Al} 2 \mathrm{O} 3$ size of 250 ? M which is to form an ideal surface texture also get metal surface thoroughly cleaned of residual plant material castings and remnants of metal oxide on the surface (co-cr) after the process casting, increase the ability of capillaries on the metal surfaces, as well as retaining the interface area to the pressure of depreciation (Knezovic 2003). Sandblasting should be able to produce dull surfaces without undercuts. Make sure always check the quality of the nozzle so as to produce the correct spray pressure. Avoid the use of repeat because it can cause excessive abrasion. The sand that is in use must be changed frequently during the sandblasting process so that the results are accurate.

Cleaning all the dirt on the surface of the metal works and is fast with high vapor pressure. After cleaning with high-pressure steam, the metal surface should not be affected fingers, grease or dust. If it can not do the cleaning metal surfaces with high vapor pressure, it can be used fluoride acid solution. The dirt that is still attached to a metal surface or dust from abrasive or planting material still attached can dissolve or disappear for no less than 10 minutes, because the acid fluoride is a material that is harmful to humans, the use of acid is limited. While the advantages of sandblasting is on a metal surface mixed base metal is to improve the smooth metal surface wetting, the pressure of the sandblasting produce a mechanical interlocking of the metal framework denture that will add strength. For sandblasting losses on metal surfaces that are excessive roughness can cause pressure centered on a metal surface, which can cause air trapped in the empty space on the metal if there are sharp corners. For sandblasting technique that if used mixed metal, the surface layer of the pipe must be cleaned with pressurized sprayers 2-3 bar. Precious metals without mixture in sandblasting with $\mathrm{Al} 2 \mathrm{O} 3$ grains with ukukuran 250? $\mathrm{M}$ and a pressure of 4-6 bar. After the sandblasting the metal framework denture should be cleaned under running water or with steam engines transmitter. Do not touch the metal frame of the denture with a finger, so that is not contaminated with oil.

The metal used for the manufacture of dentures metal frame is metal solid cobalt-chromium (co-cr alloy), nickel-chromium (ni-cr alloy) and titanium (Ti-6Al7NB alloy) (Craig \& Powers, 2002, Gerstorfe \& Paessler 2003). Titanium (Ti-6Al-7NB alloy) (Craig \& Powers, 2002, Gerstorfer \& Paessler 2003). Metal co-cr has been used for the manufacture of removable denture and denture deft and introduced to the dental profession since 1929. Virtue possessed other solid metal base metal both physical and chemical attributes, namely low density compared with a solid metallic gold, and modulus elasticity which is almost two times larger than the solid metals gold (Kueh \& Fazal 2012). Since then effectively replace metal co-cr gold solid metal type IV for the manufacture of metal frame removable dentures in part, especially since the cost is relatively cheaper, and is a significant factor to the need of making the denture metal framework (Noort 2002).

In the manufacture of metal frame removable denture, metal co-cr is a metal that is ideal, because the metal has a modulus of elasticity of about $250 \mathrm{GPa}$. By having a high modulus of elasticity, can give you an advantage in that the arms can be made thinner since clamps (Noort 2002). According to Preston \& Berger relationship between the process of sandblasting the surface roughness that sandblasting with $250 \mu \mathrm{m} \mathrm{Al} 2 \mathrm{O} 3$ particles is to create surface roughness and to clean metal surfaces. This process removes impurities on the surface of the metal, the sharp and pointed like fins due to the use of a whetstone, adding roughness to the surface area of ??the metal. Functions treatment sandblasting with $\mathrm{Al} 2 \mathrm{O} 3$ particles is to add metal surface area, increasing the ability of capillaries on the surface of the metal, and anchoring at the interface to the pressure of depreciation (Kuwata 1980). Function sandblasting with Al2O3 250 $\mu \mathrm{m}$ is to establish an ideal metal surface texture and also to clean metal surfaces (Franhouver 2008).

\section{MATERIALS AND METHODS}

This study materials include blue night to make evening models, sprue night, wetting agent, planting material 
castings (Rema exact, Dentaurum), liquid (Dentaurum), non asbestos liner. This type of research is experimental research laboratories. Samples made of metal co-cr rectangular with a length $=2 \mathrm{~mm}$, width $=2 \mathrm{~mm}$ and thickness $=2 \mathrm{~mm}$, and a handle.

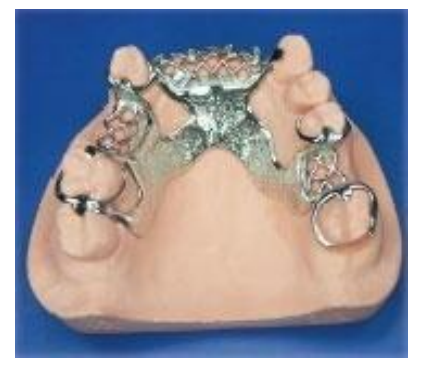

Fig. 6. Denture a metal frame with metal material co-cr (Renvert Gmbh 2008).

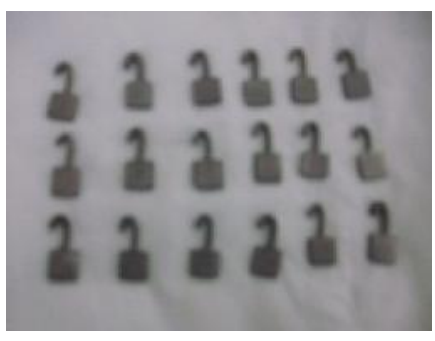

Fig. 7. Samples with $2 \times 2 \times 2 \mathrm{~mm}$ Given the size of the handle (author's documentation)

Number of samples 24 pieces divided into four groups and each group sample size 6 white. Time used in this study is 1 minute, 2 minutes and 3 minutes. This is achieved because a research already done some preliminary research. Group I is a metal surface without Sandblasting (control). Group II was sandblasting the metal surface with $\mathrm{Al} 2 \mathrm{O} 3250 \mu \mathrm{m}$ with a time of 1 minute Sandblasting on a metal surface with $\mathrm{Al} 2 \mathrm{O} 3250$ $\mu \mathrm{m}$ with a time of 2 minutes. Group III is sandblasting the metal surface with $\mathrm{Al} 2 \mathrm{O} 3250 \mu \mathrm{m}$ with a time of 3 minutes.

How it works first setting up a model night then make a sample of 24 pieces. Make sprue 3 pieces, which is 2 sprue reservoir, 1 manihold, 24 mainsprue. Making ventilation and crusible former.Yang second is planted in the casting ring. Samples that have been finished, and then installed sprue. Once it is installed on a former crusible then inserted into the casting ring is mounted non asbestos liner with the same distance from the wall casting ring in all directions. Distance from basic casting ring approximately $6-7 \mathrm{~mm}$, installed ventilation and in ulasi wetting agent. Filling planting done over the vibrator, filled up parallel to the surface of the tube tuang.Kemudian The third is to do metal casting (casting) .Caranya ie planting material that has been set, do burn-out process, approximately 30 minutes, then put in the machine furnace until the temperature reaches $10000 \mathrm{c}$. Then the casting process using a centrifugal technique. The fourth is the result of casting cleaning process. After the casting ring cool, the results cast removed from the casting ring for finishing later. Metal surface grinding, if there is a pimple or a bubble attached, provided they are not reducing metal thickness. After polishing then sandblasting the specified time. Furthermore, a fifth way is test sample. Samples were placed on the table roughness tester then the needle tip affixed to the surface of the sample, then connected on a universal tensile test equipment, then the machine is turned on it will show the value of the surface roughness. each sample was five times the measurement is then taken the average value
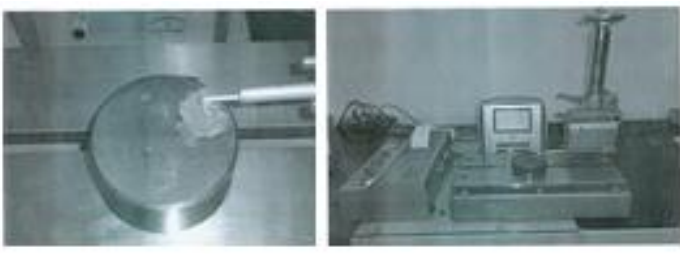

Fig. 8. Measurements of surface roughness of Sample (author's documentation)

Then the data are tabulated, then performed statistical analysis using statistical tests were as follows. The first is the normality test. To test whether the data comes from a normal distribution normality test using a histogram of Kolmogorov-Smirnov test. Then the second namely homogeneity test. To ensure that the sample comes from a homogeneous population, homogeneity test performed with Levene test. Then the last is a test Annova to see the influence of the length of time sandblasting and followed by Tukey HSD test to determine differences in the increase in the surface roughness between each treatment group and the control group.

\section{RESULTS}

From the research that has been done, the data obtained surface roughness of the metal framework denture divided into four groups: one control group and three treatment groups were in sandblasting with a time of 1 minute, 2 minutes and 3 minutes, showing the results of which can be seen in the table 1 . 
Table 1. Average and standard deviation of the number of samples on the surface roughness of metal framework denture $(\mathrm{kgf} / \mathrm{cm} 2)$.

\begin{tabular}{llcc}
\hline \multicolumn{1}{c}{ Groups } & N & X & SD \\
\hline Control & 6 & 5.833 & .7312 \\
1 minutes & 6 & 8.317 & .6274 \\
2 minutes & 6 & 9.850 & .7994 \\
3 minutes & 6 & 10.183 & .7653 \\
\hline
\end{tabular}

Before the parametric test, homogeneity test was done to determine whether the data from the laboratory parameters fifth group came from a homogeneous population and is used as a test levene homogeneity test in this study can be seen in Table 2 .

Table 2. Results of homogeneity test with levene test on a metal surface roughness $\mathrm{CoCr}$.

\begin{tabular}{llll}
\hline $\begin{array}{l}\text { Levene } \\
\text { Statistic }\end{array}$ & df1 & df2 & Sig. \\
\hline 386 & 43 & 20 & .764 \\
\hline
\end{tabular}

Found that the sample results from the first group (control), group II, group III, and IV groups was significantly different, namely the number of $\mathrm{P}=0.764$ $(\mathrm{P}>0.05)$ so that it can be concluded that the fifth group derived from a homogeneous population. Furthermore, the normality test, this test is intended to determine whether the data is normally distributed laboratory parameters used Kolmogorov Smirnov test, can be seen in Table 3.

Table 3. Results of Kolmogorov-Smirnov normality test on the surface roughness metal framework denture.

\begin{tabular}{lll}
\hline & & Roughness \\
\hline $\mathrm{N}$ & & 24 \\
Normal & Mean & 8.546 \\
Parameters ${ }^{\mathrm{b}}$ & Std. Deviation & 1.8826 \\
Most Extreme & Absolute & .136 \\
Differences & Positive & .102 \\
& Negative & -.136 \\
Kolmogorov-Smimov Z & .669 \\
Asymp. Sig. (2-tailed) & .763 \\
\hline
\end{tabular}

a. Test distribution is Normal.b. Calculated from data.

From Table 3 above shows that the data of the entire study group has a probability value of $0.763(\mathrm{P}>0.05)$ means that the data in the entire study group normally distributed. Then after the normality test and homogeneity test done one way ANOVA test with significance level of $5 \%$. The results of data analysis using one-way ANOVA test can be seen in Table 4.

Table 4. Results of one-way ANOVA test on the surface roughness of the metal frame of the denture.

\begin{tabular}{lccccc}
\hline \multicolumn{1}{c}{ Variation Source } & Sum of Square & df & Mean Square & F & $\begin{array}{c}\text { Sig. } \\
\text { (P) }\end{array}$ \\
\hline Between Groups & 70.755 & 3 & 23.585 & 43.818 & 0.000 \\
In Groups & 10.765 & 20 & .538 & & \\
Total & 81.520 & 23 & & & \\
\hline
\end{tabular}

By using ANOVA showed one path, namely: $\mathrm{F}=43$ 818 and $\mathrm{P}=0.000(\mathrm{P}<0.05)$, it can be concluded there is a significant difference from the 4 to the treatment groups. Because there is a significant difference then proceed with Tukey HSD test and get the results as listed in Table 5.

Table 5. HSD test results between the 4 groups of samples

\begin{tabular}{lcccc}
\hline \multicolumn{1}{c}{ Groups } & Control & $\begin{array}{c}1 \\
\text { minutes }\end{array}$ & 2 minutes & 3 minutes \\
\hline Control & - & $*$ & - & - \\
1 minutes & - & - & $*$ & - \\
2 minutes & - & - & - & $*$ \\
3 minutes & - & - & - & $*$ \\
\hline
\end{tabular}

From the results of HSD in getting results, there is a significant difference between each - each group. In Table 5 found significant differences in the control group to the treatment group 1 minute. On sandblasting 1 minute to 2 minutes there is also a significant difference, 2 minutes to 3 minutes to have a significant difference.

\section{DISCUSSION}

Manufacture of removable partial denture metal framework is successful if it meets the requirements that are biocompatible, comfortable, and the surfaces must be smooth (Craig \& Powers 2002, Knezovic 2003). Restoration is said to be smooth if it has the ideal 
surface roughness value. Rough surfaces can cause bacterial adhesions that would lead to bad breath, stomatitis, and the various diseases associated with the use of other artificial teeth (Quirynen \& Bollen 1995, Franunhofer 2008).

To get a smooth surface and in accordance with the terms of the creation of removable partial denture metal framework must go through the stages that have been determined, the phase of which is elektropolishing. Elektropolishing is a process of making a thin film on the surface of the metal using electric current by immersing the metal is added to a solution of electrolytes (Knezovic2003), the process of electropolishing when running perfectly then showed the surface of the metal frame of the denture is smooth and glossy (Surmann \& Huser 1998).

Phase highly influential order electropolishing process is running perfectly that stage sandblasting. Sandblasting is a process of treatment in the form of spraying abrasive particles are strong and focused on the metal surface to clean up the remnants of planting materials and metal oxides (Kumar et al 2013). The success of the process depends on the speed sandblasting or pressure spray, the particle size, the mechanical properties of the particles and the duration of the collision process (Widyarta et al 2015).

Based on the results of research on the effects of time sandblasting with the use of $\mathrm{Al} 2 \mathrm{O} 3$ on the surface roughness of the metal cobalt-chromium, obtained an average value of time sandblasting use these materials on metal co-cr with old waktu1 minutes, 2 minutes and 3 minutes presented in Table 4.1, On the table in getting the results there were significant differences in surface roughness of the metal co-cr between a control group without sprayed/in sandblasting compared with the group in the spray/disandblasting 1 minute, 2 minutes and 3 minutes. This is due to the control group who were not given the treatment compared to the group treated sandblasting there is a very significant difference. In the control group did not do so results sandblasting visible surface roughness level was so high that the results are less than the maximum and will complicate the process of finishing and polishing the denture metal framework. This is in accordance with the opinion of Knezovic (2003) that the metal surface sandblasting is done will cause inaccuracy in the fittings surface after tested on a working model. Whereas in the group treated with a surface roughness level sandblasting look down dramatically, according to the table 4.4 tedapat significant differences in surface roughness in 4 groups where $\mathrm{P}=0.000(\mathrm{P}<0.05)$.
In the group of sandblasting with a time of 1 minute compared with the surface roughness of 2 minutes there is a difference but not too significant, shown in table 4.5. On the metal surface in sandblasting with a time of 1 minute it still leaves the rest of the metal oxide, but the planting material castings attached to the metal surface is already almost gone. This is likely due to the spraying time is required to remove the remaining metal oxides and planting material is still less so the result is less than the maximum. In the group of sandblasting with a time of 2 minutes in getting the results already are the remaining metal oxides are also planting material attached to the surface of the metal was gone. This is likely due to the spraying time is needed to remove residual oxides and planting material is still less so the result is less than the maximum.

This is in accordance with the opinion of Widyarta et al (2015) that the duration of time affect the success of the sandblasting process to eliminate the planting material and the oxide layer on the metal surface. However, the value of a surface roughness has been more down than sandblasting with a time of 1 minute although the difference value is not too significant, as seen in the table 4.1.P

No sandblasting group with a time of 2 minutes compared with a surface roughness 3 minutes there is a difference but not very significant, it is probably time 2 minutes to 3 minutes distance is not much different, therefore the result is no real difference, shown in Table 4.5. On the metal surface in sandblasting with a time of 3 minutes to produce a clean metal surface without any residual oxides and there is no planting materials attached to the metal surface because the length of time of spraying. However, the value of surface roughness is up slightly compared to sandblasting with a time of 2 minutes, shown in Table 4.1. But the difference value is not so meaningful. This is because the material is $\mathrm{A} 12 \mathrm{O} 3$ sandblasting process if done for too long will lead to higher levels of surface roughness (Bousba et al 2003). Thus, by using powder Al2O3 with a size of 250 $\mu \mathrm{m}$ with a time of 2 minutes will further eliminate residual metal oxides and not a shred of planting material that sticks to the surface of the metal framework and eliminate the parts that sharp or pointed, and the value of roughness of surface is the lowest compared using a time of 1 minute, or 3 minutes as in table 4.1. This is consistent with the theory of Anusavice (2003) that the presence of particles of silica in the material quarts cristaline $\mathrm{A} 12 \mathrm{O} 3$ where the particles is very hard, and sharp shape. So as to accelerate the time the sandblasting process. 


\section{CONCLUSION}

From the results of this study concluded that the surface of the metal frame that is not done sandblasting coarser than done sandblasting. The longer the time sandblasting increasingly produce smooth surface of a metal frame. Sandblasting is perfectly need sufficient time is 2-3 minutes.

\section{REFERRENCES}

Anusavice KJ. Abrasion,Finishing and Polishing Material 11 th ed. St louis: Mosby Inc; 2003. p. 358, 369, 370.

Bousba C, Madjoubi MA, Hamidouche Z, Bououadja $\mathrm{N}$. Effect of sandblasting on soda lime glass properties. Algeria. Engineering journal of university of qatar 2003;16(1): 125-138.

Carpenter MA, Goodkind RJ. Effect of varying surface texture on strenght of one semi precious and non precious ceramo alloy. J.prosthet. Dent 1979: vol 42: pp 86-95.

Craig RG, Powers JM. Restorative Dental Material. 7 th ed. St Louis: Mosby Inc; 2002. pp 186-95,637-58

Fraunhofer JAV. Factors involved in microbial colonization of oral prostheses. Available from: http://www.agd.org/supprot/articels/?ArtID=5010.

Accessed: August 1st 2008.

Henderson, Davis ang Steffel, (1995), McCracken Removable Partial Prosthodontics, 5th ed, Mosby Company, ST. Luois, pp. 313-350.

Hudis, M.1997.Dental Laboratory Prostodontics,WB Sounders Campany, Philadelphia:London, Toronto

Knezovic D, Nemet M, Baucic I. Laboratory fibrication procedures of metal partial danture framework. Croatia: Acta Stomat Croat 2003; 37(1): 95-8.

Manappalil JJ. Basic dental materials.7th ed. New Delhi: Mosby; 2003. p: 302-7

Kueh ST, Reza F. Evaluation of physical properties and casting accuracy of chrome cobalt alloys with different casting system and investments. Malaysia: journal of physical science 2012; 23(2): 91-102.

Kumar KS, Ananda SR, Ramesh KN, Patil NP. A comparatif study of the effectivenes of metal surface threatment in controling microleakage of two diferent metal and Acrylic Resin Interface. India: Journal of dental science 2013; 1(2):7-12.

Labasova E. Measurement of changes of the surface roughness in sliding area. Slovak Republic: American International journal of contemporary research 2013: $3(4) ; 1-5$.

Loney WR. Removable partial danture manual. Dalhousie university; 2011 p. 1-2. 59. 32-56.
Noort RV. Introduction to dental materials. 2th ed. St.Louis: Mosby Inc; 2002. p. 227-9.

Pietnicki K, Woloweic E, Klimek L. The effect of abrasive blasting on the strength of a joint between dental porcelain and metal base, poland. Acta of bioenggineering and biomechanics 2014: 16(1); 6368.

Pintadi H. Kombinasi gigi tiruan kerangka logam dengan thermoplastik. Indonesia: jurnal PDGI 2013; 62(2): 45-47.

Powers JM, Wataha JC. Dental materials properties and manipulation. 9th ed. washington: Mosby Inc; 2008. p. $122,123-124$.

Prabowo T. Desain cangkolan pada gigi tiruan kerangka logam dalam usaha mendapatkan retensi gigi tiruan. Skripsi. Medan: Sarjana

Quirynen M, Bollen CM. The influence of surface roughness and surface-free energy supra and subgingival plaque formation in man. A refew of the literatur. J clin periodontol 1995; 22(1): 1-14.

Renvert . Model casting technique. Analysis, planing, and manufacture. http://www.renfert.com/fileadmin/content/pdfs/Fibeln/ Modellgussfibel/Modellgussfibel_gb.pdf . by Renfert Gmbh; 2008.

Saif corporation. Industrial Hygiene. Abrasive blasting. http://www.saif.com/_files/safetyhealthguides/ss434.pdf. Accessed: January 2008.

Singh K, Gupta N. Injection molding technique for fibrication of flexible Prosthesis for Flexible Thermoplastik danture base materials. India: World journal of dantistry 2012; 3(4): 303-7.

Surmann H, Huser J. Automatic electropolishing of cobalt chromium dental cast alloys with a fuzyy logic controller. Germany. Journal of computers \& chemical engineering 1998; 22(7-8): 1099-1111.

Slatineanu L, Potharnice S, Coteata M, Grigoras I, Gherman L, Negoeschu F. Surface roughness at alumunium parts sandblasting. Proceding in manufacturing system; Romania: 6(2); 2011.

Usdentaldepot.Sandblaster.http://www.usdentaldepot.co $\mathrm{m}$ /usdd/1/usdd_ sand-blast.pdf. Accessed: February 13 th 2016.

Wang CS, Chen KK, Tajima K, Nagamatsu Y, Kakigawa H, Kozono Y. Effect of sandblasting media and steam cleaning on bond strength of titaniumporcelain. Japan: Dental material journal 2010; 29(4): 381-91.

Widyarta IM et al. Kekasaran permukaan baja karbon sedang akibat proses sandblasting dengan variasi tekanan dan sudut penyemprotan. Proceding seminar nasional tahunan XIV; Banjarmasin, 2015, oktober 78 